\title{
ANALISIS TERHADAP PUTUSAN MAHKAMAH KONSTITUSI NOMOR 93/PUU-X/2012 TENTANG PENYELESAIAN SENGKETA PERBANKAN SYARIAH
}

\author{
Nursal \\ Hakim Pengadilan Agama Kota Sawahlunto \\ e-mail: nursal_sal@yahoo.com
}

\begin{abstract}
In this qualitative study, the researcher analyzed the effect of the decision of Constitutional Courts Number 93/PUU-X/2012 about syariah banking by litigation or non litigation. The results of this study were 1) for ligitation, the solving problems on conflict of Syariah Banking were on Religious Courts; 2) for non ligitation, it was the second choice if the consumers did not want to solve the problems on Religious Court, the solving problem was based on discussion; consultation; negositation; mediation; and expert judgment.
\end{abstract}

Keywords: Decision of Constitutional Courts, Syariah Banking, Religious Court, Litigation, Non Litigation

\section{PENDAHULUAN}

Secara yuridis formal, Peradilan Agama merupakan salah satu lembaga peradilan negara yang berwenang sebagai salah satu lembaga peradilan yang melakukan kekuasaan kehakiman (Pasal 24 ayat 2 UUD 1945) amandemen ketiga tahun 2001 dan pasal 10 Undang-Undang Nomor 4 tahun 2004 tentang kekuasaan kehakiman yang diubah lagi dengan Undang-Undang Nomor 48 tahun 2009, Peradilan Agama telah diberi kewenangan/kompetensi oleh Undang-Undang tersebut yang bersifat mengadili. Kewenangan mengadili berdasarkan Undang-undang ini menjadi kewenangan mutlak untuk memeriksa dan memutus serta menyelesaikan perkara tersebut (hingga sampai pelaksanaan eksekusi). Kewenangan mutlak ini dinamakan juga kompetensi absolut atau yuridiksi absolut, termasuk kewenangan absolut pengadilan agama untuk mengadili sengketa ekonomi syariah sebagaimana amanah dari Undang-undang Nomor 3 tahun 2006 sebagai perubahan dari Undang-Undang Nomor 7 tahun 1989 tentang Peradilan Agama.

Di dalam Undang-Undang Nomor 3 tahun 2006 perubahan atas UndangUndang Nomor 7 tahun 1989 tentang Peradilan Agama pada pasal 49 huruf (i) telah dinyatakan secara jelas bahwa Pengadilan Agama diberi kewenangan 
baru untuk memeriksa, mengadili dan menyelesaikan perkara pada tingkat pertama antara orang-orang yang beragama Islam dalam bidang ekonomi syariah yang meliputi sebagai berikut.

1. Bank Syariah;

2. Lembaga Keuangan Mikro Syariah;

3. Asuransi Syariah;

4. Reasuransi Syariah;

5. Reksadana Syariah;

6. Obligasi Syariah dan Surat Berharga Berjangka Menengah Syariah;

7. Sekuritas Syariah;

8. Pembiayaan Syariah;

9. Dana Pensiun Lembaga Keuangan Syariah; dan

10. Bisnis Syariah.

Adapun mengenai sengketa di bidang ekonomi Syariah yang menjadi kewenangan Pengadilan Agama menurut Manan (2007: 8) adalah sebagai berikut.

1. Sengketa di bidang ekonomi syariah antara lembaga keuangan dan lembaga pembiayaan syariah dengan nasabahnya;

2. Sengketa di bidang ekonomi syariah antara sesama lembaga keuangan dan lembaga pembiayaan syariah; dan
3. Sengketa di bidang ekonomi syariah antara orang-orang yang beragama Islam, yang mana akad perjanjiannya disebutkan dengan tegas bahwa kegiatan usaha yang dilakukan adalah berdasarkan prinsip-prinsip syariah.

Berdasarkan ketentuan pasal 49 Undang-Undang Nomor 3 Tahun 2006 perubahan atas Undang-Undang Nomor 7 Tahun 1989 mengandung pengertian tentang kompentensi absolut Pengadilan Agama, maka pihak-pihak yang melakukan perjanjian dengan prinsip-prinsip syariah termasuk sengketa perbankan syariah tidak dapat melakukan pilihan hukum untuk diadili dalam penyelesaian sengketanya di pengadilan lain. Apalagi, sebagaimana tercantum dalam penjelasan umum Undang-Undang Nomor 3 tahun 2006, alinea ke-2, pilihan hukum telah dinyatakan di hapus (tidak berlaku lagi, sebagaimana telah berlaku sebelumnya pada sengketa waris) (Manan, 2007: 9).

Dengan ketentuan tersebut dalam drafdraf perjanjian yang dibuat oleh bebarapa perbankan syariah berkaitan dengan perjanjian pembiayaan murabahah, akad mudharabah dan akad-akad yang lain, masih mencantumkan klausul penyelesaian sengketa di Pengadilan Negeri, jika mengacu pada penjelasan umum Undang- 
Undang Nomor 3 tahun 2006 alinea ke -2 maka klausul tersebut mestinya diubah menjadi kewenangan Pengadilan Agama dalam menyelesaikan sengketa tersebut.

Dua tahun berselang sejak diundangkan Undang-Undang Nomor 3 tahun 2006 perubahan atas Undang-Undang Nomor 7 Tahun 1989 tentang Peradilan Agama, pada tanggal 16 Juli 2008, diundangkan lagi Undang-Undang Nomor 21 tahun 2008 tentang Perbankan Syariah. Sebenarnya Undang-undang ini memperkuat ekonomi syariah khususnya perbankan syariah di bumi Indonesia, karena telah memiliki landasan hukum yang kuat eksisnya perbankan syariah.

Akan tetapi ada sebuah pasal dalam Undang-Undang Nomor 21 tahun 2008 tentang Perbankan Syariah khususya pasal 55 beserta penjelasannya menimbulkan polemik hukum, yang pada mulanya berdasarkan ketentuan Pasal 49 UndangUndang Nomor 3 tahun 2006 telah nyata bahwa Pengadilan Agama sebagai satusatu lembaga peradilan yang berwenang menyelesaikan sengketa ekonomi syariah termasuk di dalamnya sengketa perbankan syariah, sedangkan dalam ketentuan Pasal 55 Undang-Undang Nomor 21 Tahun 2008 beserta penjelasannya menyebutkan sebagai berikut.

\section{Pasal 55}

1. Penyelesaian sengketa Perbankan Syari'ah dilakukan oleh Pengadilan Agama

2. Dalam hal para pihak telah memperjanjikan penyelesaian sengketa selain sebagaimana dimaksud pada ayat (1), penyelesaian sengketa dilakukan sesuai isi akad.

3. Penyelesaian sengketa sebagaimana dimaksud pada ayat (2) tidak boleh bertentangan dengan prinsip syariah.

\section{Penjelasan Pasal 55}

1. Cukup jelas

2. Yang dimaksud dengan Penyelesaian sengketa dilakukan sesuai akad adalah upaya sebagai berikut.
a. Musyawarah;
b. Mediasi Perbankan;
c. Melalui Badan Arbitrase Syariah Nasional (Basyarnas) atau Lembaga arbitrase lain, dan atau
d. Melalui Pengadilan dalam lingkungan dalam Peradilan Umum.

Apabila ditelesuri ketentuan Pasal 55 Undang-Undang Nomor 21 tahun 
2008 di atas pada ayat (1) secara jelas dan tegas menyatakan bahwa lembaga yang berwenang untuk menyelesaikan (menerima, mengadili dan memutus) sengketa perbankan syariah adalah Pengadilan Agama. Hal ini telah sejalan dan sesuai dengan ketentuan Pasal 49 huruf (i) Undang Nomor 3 tahun 2006 tentang Peradilan Agama. Namun yang menjadi persoalan dan polemik hukum adalah ketentuan ayat (2) beserta penjelasannya Pasal 55 Undang-Undang Nomor 21 Tahun 2008 tentang Perbankan Syariah disebutkan bahwa "dalam hal para pihak telah memperjanjikan penyelesaian sengketa selain sebagaimana dimaksud pada ayat (1) penyelesaian sengketa dilakukan sesuai isi akad. Yang dimaksud dengan penyelesaian sengketa dilakukan sesuai akad adalah upaya sebagai berikut.

1. Musyawarah;

2. Mediasi Perbankan;

3. Melalui Badan Arbitrase Syariah Nasional (Basyarnas) atau Lembaga Arbitrase lain, dan atau

4. Melalui Pengadilan dalam lingkungan dalam Peradilan Umum.

Jika diperhatikan ketentuan Pasal 55 Undang-Undang Nomor 21 tahun 2008 tentang perbankan Syariah beserta penjelasannya, maka penyelesaian sengketa perbankan syariah dapat ditempuh melalui jalur litigasi dengan dua badan peradilan yang bisa menyelesaikan sengketanya yaitu Peradilan Agama dan Peradilan Umum. Dari kondisi ini akan melahirkan ketidakpastian hukum pengadilan mana yang seharusnya berwenang untuk menyelesaikan sengketa perbankan syariah. Sehingga para pencari keadilan tidak bingung mau ke peradilan mana semestinya diajukan sengketa Perbankan Syariah ini.

Apakah kewenangan absolut Pengadilan Agama semula telah ditentukan oleh Undang-Undang Nomor 3 tahun 2006 atau kewenangan Peradilan Umum berdasarkan ketentuan dalam penjelasan ayat (2) Pasal 55 Undang-undang Nomor 21 tahun 2008? Begitu pula ketentuan Pasal 55 ayat (2) Undang-Undang Nomor 21 tahun 2008 dan penjelasannya juga memuat penyelesaian sengketa perbankan syariah melalui non litigasi (di luar badan peradilan) di antaranya musyawarah, mediasi perbankan, melalui Badan Arbitrase Syariah Nasional (Basyarnas) atau badan arbitrase lain.

Ketidakpastian hukum tersebut, lembaga peradilan mana yang berwenang menyelesaikan sengketa perbankan syariah beberapa forum melalui non 
litigasi sehingga memunculkan istilah choice of forum. Oleh karena tidak adanya kepastian hukum lembaga peradilan mana yang berwenang, maka seorang nasabah dari Bank Muamalat Indonesia Tbk. Cabang Bogor bernama Dadang Achmad mengajukan uji materiil (judicial review) ke Mahkamah Konstitusi terhadap Undang-Undang Nomor 21 tahun 2008 tentang Perbankan Syariah pasal 55 ayat (2) dan (3) dengan surat permohonan tertanggal 12 Agustus 2012 yang diterima kepaniteraan Mahkamah Konstitusi pada tanggal 12 September 2012.

Pengajuan tersebut telah dicatat dalam Buku Registrasi Perkara Mahkamah Konstitusi pada tanggal 24 September 2012 dengan Nomor 93/PUU-X/2012 yang pada pokok permohonannya adalah bahwa Undang-Undang Dasar 1945 Pasal 28 D ayat (1) secara tegas mengatur bahwa Undang-Undang harus menjamin adanya kepastian hukum dan keadilan. Jika melihat Pasal 55 Undang-Undang Nomor 21 tahun 2008 tentang Perbankan Syariah, yaitu antara ayat (1) dengan ayat (2) dan ayat (3) terdapat kontradiktif, di mana yang satu secara tegas menyebutkan lembaga penyelesaian sengketa dan yang lainnya membebaskan untuk memilih lembaga tersebut.
Dengan adanya kontradiktif tersebut antara yang satu dengan yang lainnya lahirlah penafsiran sendiri-sendiri sehingga makna kepastian hukum menjadi tidak ada (Mahkamah Konstitusi, 2013). Selanjutnya Mahkamah Konstitusi telah melakukan sidang atas judicial review tersebut dan memutuskan pada tanggal 29 Agustus 2013 dengan Nomor 93/PUU-X/2012 yang amarnya berbunyi sebagai berikut (Mahkamah Konstitusi, 2013).

\section{Mengadili}

\section{Menyatakan:}

1. Mengabulkan permohonan Pemohon untuk sebagian;

a. Penjelasan Pasal 55 ayat (2) Undang-Undang Nomor 21 tahun 2008 tentang Perbankan Syariah (Lembaran Negara Republik Indonesia Tahun 2008 Nomor 94, Tambahan Lembaran Negara Republik Indonesia Nomor 4867) bertentangan dengan Undang-Undang Dasar Negara Republik Indonesia tahun 1945; dan

b. Penjelasan Pasal 55 ayat (2) Undang-Undang Nomor 21 Tahun 2008 tentang Perbankan Syariah ( Lembaran Negara Republik Indonesia tahun 
2008 Nomor 94, Tambahan Lembaran Negara Republik Indonesia Nomor 4867) tidak mempunyai kekuatan hukum mengikat.

2. Memerintahkan pemuatan putusan ini dalam Berita Negara Republik Indonesia sebagaimana mestinya; dan

3. Menolak permohonan Pemohon untuk selain dan selebihnya

Dengan adanya putusan Mahkamah Konstitusi Nomor 93/PUU-X/2012, maka penelitian ini akan menganalisis bagaimana akibat hukum terhadap proses litigasi dan non litigasi dalam penyelesaian sengketa perbankan syariah.

\section{METODE PENELITIAN}

Jenis penelitian ini bersifat kualitatif induktif dengan metode deskriptif. Menurut Cresswell (2008) "an inductive approach aimed at reducing the data into a manageable number of themes that addressed the concerns of the study". Metode kualitatif ini dipilih karena 1) dilaksanakan pada kondisi yang alamiah; 2) lebih bersifat deskriptif, sumber data utama dalam penelitian kualitatif adalah kata-kata dan tindakan, sehingga tidak menekankan pada angka; 3) lebih menekankan pada proses daripada produk atau outcome; 4) analisis data dilakukan secara induktif; dan 5) lebih menekankan makna (data dibalik yang teramati) (Sugiyono, 2007: 9). Dalam mengumpulkan data yang dibutuhkan, peneliti menggunakan teknik pengumpulan data wawancara dan studi dokumen. Analisis data dilakukan melalui 3 tahap, yaitu data reduction (reduksi data); data display (penyajian data); dan Conclusion Drawing/Verification (Kesimpulan). Menurut Moleong, (2007: 307) aktivitas dalam analisis data kualitatif dilakukan secara interaktif dan berlangsung secara terus menerus pada setiap tahapan penelitian sehingga sampai tuntas, dan datanya sampai jenuh.

\section{HASIL PENELITIAN DAN PEMBAHASAN}

1. Akibat Hukum Putusan Mahkamah Konstitusi Nomor 93/PUU-X/2012 Terhadap Penyelesaian Sengketa Perbankan Syariah Secara Litigasi

Terbitnya Putusan Mahkamah Konstitusi Nomor 93/PUU-X/2012, memiliki akibat hukum mekanisme penyelesaian sengketa perbankan syariah secara litigasi karena penjelasan Pasal 55 ayat (2) Undang-Undang Nomor 21 Tahun 2008 tentang Perbankan Syariah dihapus secara keseluruhan. 
Dengan demikian, ketentuan penyelesaian sengketa perbankan syariah secara litigasi kembali kepada pasal induknya yaitu Pasal 55 ayat (2). Menurut ketentuan pasal induk tersebut (Pasal 55 ayat 2) penyelesaian sengketa dapat dilakukan sesuai dengan akad, jika hal ini diberlakukan kembali secara bebas, membuka peluang para pihak bersepakat memilih Pengadilan Negeri sebagai lembaga penyelesai secara litigasi sengketa para pihak dapat muncul kembali.

Jika dianalisis lebih jauh para pihak yang memilih kembali ke Pengadilan Negeri ini bertentangan dengan Konstitusi serta ketentuan UndangUndang Nomor 3 Tahun 2006 Pasal 49 huruf (i), sehingga tidak ada pilihan lain penyelesaian sengketa perbankan syariah secara litigasi adalah Pengadilan Agama. Kemudian bagaimana akibat hukum dari sebuah putusan Mahkamah Konstitusi terutama dalam hal permohonan uji materiil sebuah undang-undang. Menurut ketentuan Pasal 47 Undang-Undang Nomot 24 tahun 2003 diubah dengan UndangUndang Nomor 8 tahun 2011 tentang Mahkamah Konstitusi di jelaskan "putusan Mahkamah Konstitusi memperoleh kekuatan hukum tetap sejak selesai diucapkan dalam sidang Pleno terbuka untuk umum“.

Kemudian dijelaskan lagi pada Pasal 56 (ayat 2) Undang-Undang Nomor 24 Tahun 2003 kemudian diubah dengan Undang-Undang Nomor 8 tahun 2011 tentang Mahkamah Konstitusi yang berbunyi "dalam hal permohonan dikabulkan sebagaimana dimaksud pada ayat (2), Mahkamah Konstitusi menyatakan dengan tegas materi muatan ayat, pasal dan/atau bagian dari undang-undang yang bertentangan dengan UUD Republik Indonesia Tahun 1945. Selanjutnya, dalam pasal 57 (ayat 1) dalam UndangUndang tersebut dinyatakan pula bahwa "putusan Mahkamah Konstitusi yang amar putusannya menyatakan bahwa materi muatan ayat, pasal dan/atau bagian dari undang-undang yang bertentangan dengan UUD Republik Indonesia Tahun 1945 materi muatan ayat, pasal dan/atau bagian dari undang-undang tersebut tidak mempunyai hukum".

Dari pernyataan pasal-pasal Undang-Undang tersebut di atas dapat dipahami bahwa setelah pengujian atas Undang-Undang itu diputus final, maka seperti dijelaskan oleh Pasal 47 Undang-Undang Nomor 24 
tahun 2003 diubah dengan UndangUndang Nomor 8 tahun 2011 tentang Mahkamah Konstitusi, putusan itu langsung berlaku mengikat sejak diucapkan dalam sidang pleno terbuka untuk umum. Artinya efek keberlakuannya bersifat prospektif ke depan (forward looking), bukan berlaku ke belakang (backward looking). Maksud forward looking bukan backward looking adalah bahwa putusan Mahkamah Konstitusi tersebut tidak berlaku surut.

Apabila dihubungkan dengan pengujian materiil Undang-Undang Nomor 21 tahun 2008 tentang Perbankan Syariah maka sejak diucapkan sidang pleno yang terbuka umum oleh Mahkamah Konstitusi pada tanggal 29 Agustus 2013 secara otomatis langsung berkekuatan hukum tetap dan putusan tersebut bersifat final. Substansi pokok dari putusan Mahkamah Konstitusi tersebut adalah "penjelasan pasal 55 ayat (2) Undang-Undang Nomor 21 tahun 2008 tentang Perbankan Syariah (Lembaran Negara Republik indonesia Tahun 2008 Nomor 94, Tambahan Lembaran Negara Republik Indonesia Nomor 4867) bertentangan dengan Undang-Undang Dasar Negara Republik Indonesia tahun 1945 dan Penjelasan Pasal 55 ayat (2) Undang-
Undang Nomor 21 Tahun 2008 tentang Perbankan Syariah (Lembaran Negara Republik Indonesia Tahun 2008 Nomor 94, Tambahan Lembaran Negara Republik Indonesia Nomor 4867) tidak mempunyai kekuatan hukum mengikat".

Adapun bunyi penjelasan pasal 55 ayat (2) Undang-Undang Nomor 21 tahun 2008 tentang Perbankan Syariah bertentangan dengan Undang-Undang Dasar Negara Republik Indonesia tahun 1945 serta tidak mempunyai kekuatan hukum mengikat adalah “yang dimaksud dengan penyelesaian sengketa dilakukan sesuai akad adalah upaya sebagai berikut a) musyawarah; b) mediasi perbankan; c) melalui Badan Arbitrase Syariah Nasional (Basyarnas) atau Lembaga arbitrase lain, dan atau d) melalui Pengadilan dalam lingkungan dalam Peradilan Umum".

Berdasarkan putusan Mahkamah Konstitusi Nomor 93/PUU-X/2012 tersebut yang berkaitan dengan penyelesaian sengketa perbankan syariah secara litigasi dalam penjelasan pasal 55 ayat (2) poin d yang menyatakan "melalui Pengadilan dalam lingkungan peradilan umum", maka dapat dipahami bahwa penjelasan pasal 55 ayat (2) poin $\mathrm{d}$ tersebut bertentangan 
dengan Undang-Undang Dasar Tahun 1945 dan tidak mempunyai kekuatan hukum mengikat. Berarti ketentuan penjelasan Pasal 55 ayat (2) poin d yang menyatakan penyelesaian sengketa perbankan syariah yang dibuat berdasarkan akad "melalui Pengadilan dalam lingkungan peradilan umum", sejak terhitung tanggal 29 Agustus 2013, di mana diucapkannya putusan Mahkamah Konstitusi Nomor 93/ PUU-X/ 2012 tidak dapat diberlakukan lagi karena dinyatakan bertentangan dengan Undang-Undang Dasar 1945 serta tidak memiliki kekuatan hukum mengikat.

Berdasarkan ketentuan tersebut penyelesaian sengketa perbankan syariah kembali ke pada Pasal Induknya yaitu Pasal ayat (2) namun jika akad itu masih mencantumkan pengadilan negeri tetap bertentangan dengan Konstistusi maka semestinya dikembalikan juga kepada Pasal induk ayat 1 (Pasal 55 Undang-Undang Nomor 21 Tahun 2008) secara tegas menyatakan bahwa "penyelesaian sengketa perbankan syariah dilakukan oleh pengadilan dalam lingkungan Peradilan Agama". Oleh sebab itu penyelesaian sengketa perbankan syariah secara litigasi sejak tanggal
29 Agustus 2013 telah menjadi kewenangan penuh Pengadilan Agama tidak ada lagi dualisme badan peradilan yang memiliki kewenangan dalam penyelesaian sengketa perbankan syariah. Pengadilan Agama sebagai lembaga penyelesaian sengketa perbankan secara litigasi adalah sangat tepat serta telah memiliki legalitas hukum yang kuat serta merupakan amanah dari Pasal 49 huruf (i) Undang-Undang Nomor 3 tahun 2006 tentang perubahan atas UndangUndang Nomor 7 tahun 1989 tentang Peradilan Agama serta sejalan dengan ketentuan Pasal 55 ayat (1) UndangUndang Nomor 21 tahun 2008 tentang Perbankan Syariah.

2. Akibat Hukum Putusan Mahkamah Konstitusi Nomor 93/PUU-X/2012 Terhadap Penyelesaian Sengketa Perbankan Syariah Secara Non Litigasi.

Terbitnya Putusan Nomor 93/ PUU-X/2012 juga berimplikasi hukum terhadap penyelesaian sengketa perbankan syariah secara non litigasi, sebagaimana pada penjelasan di atas tertutupnya pilihan hukum secara litigasi ke Pengadilan Negeri karena bertentangan dengan Konstitusi dan Undang-Undang yang mengatur 
kewenangan masing-masing badan peradilan. Selanjutnya ada dua pilihan forum bagi para pihak dalam penyelesaian sengketa perbankan syariah melalui litigasi (Pengadilan Agama) dan non litigasi.

Pada pilihan forum non litigasi akibat hukum dari putusan Mahkamah Konstitusi tersebut, dibuka perluasan/ kebebasan lembaga non litigasi sesuai dengan maksud ayat (2) Pasal 55 Undang-Undang Nomor 21 Tahun 2008. Adapun pilihan forum non litigasi yang tersebut dalam penjelasan Pasal 55 ayat (2) Undang-Undang Nomor 21 Tahun 2008 tentang Perbankan Syariah adalah sebagai berikut.

\section{a. Musyawarah}

Adanya penyelesaian sengketa perbankan syariah secara non litigasi dipahami berdasarkan ketentuan Pasal 55 ayat (2) UndangUndang Nomor 21 tahun 2008 yang dibuat berdasarkan akad/ perjanjian.Di dalam penjelasan Undang-Undang tersebut poin (a) bentuk penyelesaian sengketa perbangkan syariah secara non litigasi adalah melalui musyawarah. Penyelesaian secara musyawarah ini harus dinyatakan dalam sebuah klausula akad atau perjanjian antara pihak perbankan syariah dengan nasabah sebagai bagian dari pilihan forum hukum (choice of forum).

Sebagai contoh sebagai akad/ perjanjiannya "apabila di kemudian hari terjadi perselisihan dalam melaksanakan akad ini maka pihak pertama (bank Syariah) dengan pihak kedua akan menyelesaikannya secara musyawarah dan mufakat". Akad atau perjanjian yang dibuat secara sah, dapat berlaku sebagai undang-undang bagi pihak-pihak yang membuatnya. Setiap perjanjian, mengikat dan mempunyai akibat hukum para pihakyang membuatnya dalam hal ini antara nasabah dan bank syariah.

Demikian pula menurut ketentuan 1338 KUHP Perdata ayat (1) menyebutkan "semua perjanjian yang dibuat secara sah berlaku sebagai Undang-Undang bagi mereka yang membuatnya“. Kata "semua" dipahami mengandung asas kebebasan berkontrak yaitu asas yang memberikan kebebasan kepada para pihak untuk a) membuat atau tidak membuat perjanjian; b) mengadakan perjanjian dengan siapapun; c) menentukan 
isi perjanjian, pelaksanaan dan persyaratannya; dan d) menentukan bentuk perjanjian yaitu secara tertulis atau lisan.

Berdasarkan kepada putusan Mahkamah konstitusi di dalam amar putusannya menyatakan semua penjelasan Pasal 55 ayat (2) Undang-Undang Nomor 21 Tahun 2008 tentang perbankan syariah bertentangan dengan UndangUndang Dasar Republik Indonesia tahun 1945 dan tidak memiliki kekuatan hukum yang mengikat.

Maka akibat hukum yang ditimbulkan dari putusan Mahkamah Konstitusi tersebut terhadap penyelesaian sengketa Perbankan Syariah secara non litigasi melalui musyawarah yang tercantum pada poin (a) dalam penjelasan Pasal 55 ayat (2) adalah tidak memiliki kekuatan hukum mengikat lagi sejak tanggal 29 Agustus 2013 karena bertentang konstitusi maka untuk penyelesaian sengketa perbankan syariah secara non litigasi dalam hal ini poin (a) musyawarah harus dikembalikan kepada Pasal Induknya yaitu Pasal 55 ayat (2) dan (3).

\section{b. Mediasi Perbankan}

Penyelesaian sengketa perbankan syariah secara non litigasi yang kedua menurut penjelasan Pasal 55 ayat 2 Undang-Undang Nomor 21 Tahun 2008 adalah mediasi perbankan [penjelasan Pasal 55 ayat (2) huruf (b)]. Dalam Peraturan Bank Indonesia (PBI) Nomor 8/5/PBI/2006 tentang Mediasi Perbankan Pasal 1 angka (5) dijelaskan mediasi adalah proses penyelesaian sengketa yang melibatkan mediator yang membantu para pihak yang bersengketa guna mencapai penyelesaian dalam bentuk kesepakatan sukarela terhadap sebagian ataupun seluruh permasalahan yang disengketakan. Kemudian dalam Pasal 2 dijelaskan mediasi perbankan merupakan penyelesaian sengketa antara nasabah dengan bank (syariah) yang disebabkan tidak dipenuhinya tuntunan financial nasabah oleh bank dalam penyelesaian pengaduan nasabah.

Pada Pasal 9 dalam Peraturan Bank Indonesia di atas dimuat bahwa antara nasabah dan bank menanda tangani perrjanjian mediasi. Dalam artian membuat 
akad (kesepakatan kedua belah pihak). Antara nasabah dan bank membuat akad secara tertulis yang memuat salah satu klausul akad/ perjanjian itu adalah jika terjadi perselisihan (sengketa) kedua belah pihak maka diselesaikan melalui jalur mediasi perbankan.

Dalam Pasal 1 angka 5 UndangUndang Nomor 19 Tahun 2008 akad didefinisikan dengan "perjanjian tertulis yang tidak bertentangan dengan prinsip syariah dan sesuai dengan peraturan perundangundangan". Sementara itu Pasal 1 angka 13 Undang-Undang nomor 21 Tahun 2008 menyatakan akad adalah "kesepakatan antara Bank Syariah atau Unit Usaha Syariah dan pihak lain yang memuat adanya hak dan kewajiban bagi masingmasing pihak sesuai dengan prinsip syariah".

Dengan adanya akad di dalam penyelesaian sengketa perbankan syariah melalui mediasi perbankan, antara nasabah dan pihak perbankan syariah terikat dengan butir-butir perjanjian itu, sekaligus menjadi undang-undang bagi mereka, walaupun dalam Pasal 6 ayat (1) PBI Nomor 8/5/PBI/2006 mediasi perbankan terbatas dalam jumlah tuntutan finansial. Pasal 6 ayat (1) tersebut menyebutkan "mediasi perbankan sebagaimana dimaksud pasal 2 untuk setiap sengketa yang memiliki nilai tuntutan financial paling banyak Rp. 500.000.000,00. (lima ratus juta rupiah).

Terbitnya putusan Mahkamah Konstitusi Nomor 93/PUU-X/2012 yang intinya menyatakan bahwa keseluruhan penjelasan Pasal 55 ayat (2) Undang-Undang Nomor 21 Tahun 2008 tentang Perbankan Syariah bertentangan dengan Undang-Undang Dasar Republik Indonesia tahun 1945 dan tidak memiliki kekuatan hukum yang mengikat. Berdasarkan ketentuan putusan Mahkamah Konstitusi tersebut, mediasi perbankan sebagaimana yang disebutkan dalam penjelasan pasal 55 ayat (2) poin $b$ adalah batal demi hukum karena bertentangan dengan Undang-Undang Dasar 1945 serta tidak memiliki kekuatan hukum yang mengikat sejak tanggal 29 Agustus 2013.

Akibat hukum dari putusan Mahkamah konstusi tersebut 
adalah mediasi perbankan yang dilaksanakan sebelum terbitnya putusan Mahkamah Kontitusi maka mediasi tersebut tetap sah. Sedangkan mediasi perbankan setelah terbitnya putusan Mahkamah Konstitusi tersebut maka akad perjanjian tersebut batal demi hukum jika ingin dilanjutkan mesti diperbaharui sesuai serta dikembalikan kepada Pasal induk yaitu Pasal 55 ayat (2) dan (3) .

\section{c. Badan Arbitrase Syariah Nasional}

Arbitrase adalah suatu proses yang mudah yang dipilih oleh para pihak secara sukarela yang ingin perkaranya diputus oleh juru pisah yang netral yang sesuai dengan pilihan mereka. Para pihak setuju sejak semula untuk menerima putusan tersebut secara final dan mengikat (Ka'bah, 2009: 1).

Adapun perjanjian arbitrase semata-mata ditujukan kepada masalah penyelesaian perselisihan yang timbul dari perjanjian. Para pihakdapatmenentukankata sepakat agar penyelesaian perselisihan yang timbul dari perjanjian tidak diajukan dan diperiksa oleh badan peradilan resmi.
Badan Arbitrase Syariah Nasional (Basyarnas) adalah perubahan nama dari Badan Arbitrase Muamalat Indonesia (BAMUI). Penyelesaian sengketa perbankan syariah melalui Badan Arbitrase Syariah Nasional (Basyarnas) merupakan bagian dari penyelesaian sengketa secara non litigasi menurut ketentuan penjelasan Pasal 55 ayat (2) huruf (c) sepanjang diperjanjikan di dalam akad, ada tercantum klausula arbitrase di dalam akad/ perjanjian tersebut. Di dalam teori hukum boleh juga membuat perjanjian arbitrase setelah terjadi perselisihan dinamakan dengan akta kompromis.

Dalam realitasnya Muhammad Syafi'i Antonio (Saksi ahli yang dihadirkan MK dalam perkara Nomor 93/PUU-X/2012) menyatakan bahwa dengan adanya pilihan forum (choice of forum) yang dibuka oleh ketentuan Pasal 55 ayat (2) Undang-undang Nomor 21 Tahun 2008 dan penjelasannya, kejadian conflict of dispute setlemen (pertentangan mengenai lembaga penyelesaian sengketa) ini sudah belasan kali atau malah puluhan kali 
terjadi baik antara Badan Arbitrase Syariah Nasional (Basyarnas) dengan Pengadilan Negeri atau antara Basyarnas dengan Pengadilan Agama atau Pengadilan Agama dengan Pengadilan Negeri sehingga menimbulkan kegaduhan hukum serta kebinggungan hukum bagi pencari keadilan.

Dengan terbitnya Putusan Mahkamah Konstitusi Nomor 93/ PUU-X / 2012 yang menyatakan bahwa penjelasan Pasal 55 ayat (2) Undang-Undang Nomor 21 Tahun 2008 tentang perbankan syariah secara keseluruhan bertentangan dengan Undang-Undang Dasar Republik Indonesia tahun 1945 dan tidak memiliki kekuatan hukum yang mengikat. Berdasarkan ketentuan dari putusan Mahkamah Konstitusi tersebut dipahami bahwa semua penjelasan yang tertera dalam pasal 55 ayat (2) khusus poin (c) yaitu Badan Arbitrase Syariah Nasional (Basyarnas) dan arbitrase lain adalah bertentangan dengan konstitusi dan tidak memiliki kekuatan hukum mengikat sejak putusan Mahkamah Konstitusi dibacakan yaitu tanggal 29 Agustus 2013.
Sehingga dari Putusan Mahkamah Konstitusi tersebut menimbulkan akibat hukum bahwa klausula arbitrase yang dibuat oleh Nasabah dengan BankSyariah yang dibuat sebelum keluarnya putusan Mahkamah Konstitusi tersebut tetap sah secara hukum sedangkan klausula yang dibuat sesudah keluarnya putusan Mahkamah Konstitusi tidak sah lagi batal demi hukum, maka mesti dikembalikan dan disesuaikan dengan pasal induknya yaitu Pasal 55 ayat (2) dan ayat (3).

Menurut analisis peneliti, Mahkamah Konstitusi dengan Putusan Nomor 93/PUU-X/2012 yang amarnya menyatakan bahwa penjelasan Pasal 55 ayat 2 secara keseluruhan ada 4 poin, berupa penyelesaian sengketa dilakukan sesuai akad adalah upaya a) musyawarah; b) mediasi perbankan; c) melalui Badan Arbitrase Syariah Nasional (Basyarnas) atau Lembaga arbitrase lain; dan atau d) melalui pengadilan dalam lingkungan dalam Peradilan Umum bertentangan dengan Konstitusi (Undang-Undang Dasar 
tahun 1945) serta tidak mempunyai kekuatan hukum mengikat.

Oleh karena semua penjelasan Pasal 55 ayat (2) bertentangan dengan Konstitusi dan tidak mempunyai kekuatan hukum mengikat maka aturan tersebut kembali kepada norma utamanya (ideal norm) yaitu Pasal 51 ayat (1), Pasal 55 ayat (2) dan Pasal 55 ayat (3). Penjelasan Pasal 55 ayat 2 hanyalah penjabaran dari makna/ maksud dari pasal utamanya (Pasal 55 ayat 2). Pada saat penjelasan sebagai penjabaran dari makna/ maksud dari pasal utama (induk) nya bertentangan dengan konstitusi maka akan kembali ke semula (ke pasal induknya).

Sebagai akibat hukum dari putusan Mahkamah Konstitusi tersebut terhadap penyelesaian sengketa perbankan syariah adalah sebagai berikut.

1) Secara yuridis bahwa semua bentuk pilihan forum (choice of forum) penyelesaian sengketa yang tertera di dalam penjelasan Pasal 55 ayat (2) tidak mempunyai hukum mengikat, baik secara penyelesaian sengketa perbankan syariah secara litigasi maupun non litigasi;

2) Oleh sebab itu, penyelesaian sengketa perbankan syariah mesti kembali kepada pasal utama/induknya yaitu Pasal 55 ayat (1), ayat (2) dan ayat (3) Undang-Undang Nomor 21 tahun 2008 tentang Perbankan Syariah;

3) Penyelesaian sengketa perbankan syariah secara litigasi kembali ke pasal utama yaitu Pasal 55 ayat 1 secara tegas menyataka "penyelesaian sengketa perbankan syariah dilakukan oleh pengadilan dalam lingkungan Peradilan Agama" maka Pengadilan Agama sebagai satu-satunya lembaga peradilan yang berwenang "menerima, memeriksa, mengadili dan menyelesaikan sengketa perbankan syariah"; dan

4) Penyelesaian sengketa perbankan syariah secara non litigasi juga kembali kepada Pasal Utama yaitu Pasal 55 ayat (2) yang menyatakan “dalam hal 
para pihak telah memperjanjikan penyelesaian sengketa selain sebagaimana dimaksud pada ayat (1), penyelesaian sengketa dilakukan sesuai dengan isi akad".

Berdasarkan ketentuan Pasal utama ini maka choice of forum penyelesaian sengketa secara non litigasi tetap diakui oleh Undang-Undang tersebut dengan menghubungkan dengan Pasal 55 ayat 3 yang berbunyi "penyelesaian sengketa sebagaimana dimaksud pada ayat 2 tidak boleh bertentangan dengan prinsip syariah". Jika dianalisis lebih lanjut bahwa penyelesaian sengketa secara non litigasi/ diluar pengadilan agama tidak hanya terbatas dalam 3 bentuk saja yaitu a) musyawarah; b) mediasi perbankan; c) basyarnas atau arbitrase lainnya tetapi lebih luas dan lebih banyak sepanjang tidak berbenturan dengan prinsip-prinsip syariah diantaranya bisa dengan cara APS (Alternatif Penyelesaian sengketa) berupa Konsultasi, negosiasi, mediasi, konsiliasi dan penilaian para ahli.

Namun yang terpenting bahwa pilihan forum (choice of forum) merupakan pilihan kedua (second choice) bilamana para pihak tidak sepakat menyelesaikan sengketanya di Pengadilan Agama dengan syarat para pihak membuat kesepakatan secara tertulis dalam sebuah akta dan di dalam akta tersebut lengkap termuat mengenai hak dan kewajiban masing-masing pihak. Hal ini juga menjadi pertimbangan hukum oleh Mahkamah Konstitusi dinyatakan bahwa menimbang, bahwa secara sistematis, pilihan forum hukum untuk penyelesaian sengketa sesuai dengan akad adalah pilihan kedua bilamana para pihak tidak bersepakat untuk menyelesaikan sengketa melalui Pengadilan Agama. Dengan demikian pilihan forum hukum untuk menyelesaikan sengketa perbankan syariah harus tertera secara jelas dalam akad (perjanjian). Para pihak harus bersepakat untuk memilih salah satu forum hukum dalam penyelesaian sengketa bilamana para pihak tidak ingin menyelesaikannya melalui Pengadilan Agama (Putusan Mahkamah Konstitusi Nomor 93/PUU-X/2012 tanggal 29 Agustus 2013).

Selanjutnya dari Putusan Mahkamah Konstitusi Nomor 93/PUU-X/2012 tersebut timbul pertanyaan apa sebabnya Mahkamah Konstitusi menyatakan semua penjelasan Pasal 55 Undang-Undang Nomor 21 Tahun 2008 tentang Perbankan Syariah bertentangan dengan Konstitusi dan tidak memiliki kekuatan hukum mengikat? atau dapat juga di pertanyakan kenapa tidak penjelasan Pasal 55 Undang- 
Undang Nomor 21 Tahun 2008 huruf (d) melalui Pengadilan dalam lingkungan peradilan umum yang bertentangan dengan Konstitusi dan tidak memiliki kekuatan hukum mengikat.

Menurut analisis peneliti, secara subtansi penyelesaian sengketa perbankan syariah yang bertentangan dengan Konstitusi/ Undang-Undang Dasar 1945 adalah penjelasan Pasal 55 huruf (d), munculnya kewenangan Pengadilan Negeri/Peradilan Umum untuk menyelesaikan sengketa perbankan syariah, padahal pada UndangUndang sebelumya yaitu Undang-Undang Nomor 3 Tahun 2006 Perubahan atas Undang-Undang Nomor 7 tahun 1989 tentang Peradilan Agama Pasal 49 huruf (i) memberikan kewenangan kepada Pengadilan Agama untuk mengadili dan menyelesaikan sengketa ekonomi syariah termasuk di dalamnya sengketa perbankan syariah.

Begitu pula dalam Konstitusi/UndangUndang Dasar 1945 telah dinyatakan bahwa adanya badan peradilan sesuai dengan kewenangan, badan peradilan tersebut adalah Peradilan Umum, Peradilan Agama, Peradilan Militer dan Peradilan Tata Usaha Negara. Dalam Undang-Undang Dasar 1945 telah ditentukan kewenangan masingmasing Pengadilan tersebut yaitu sebagai berikut. a. Peradilan Umum berwenang memeriksa, mengadili, dan memutus perkara pidana dan perdata sesuai dengan ketentuan peraturan perundang-undangan [Pasal 25 ayat (2) UUD 1945].

b. Peradilan Agama berwenang memeriksa, mengadili, memutus, dan menyelesaikan perkara antara orangorang yang beragama Islam sesuai dengan ketentuan peraturan perundangundangan [Pasal 25 ayat (3) UUD 1945].

c. Peradilan Militer berwenang memeriksa, mengadilai dan memutus perkara tindak pidana militer sesuai dengan ketentuan peraturan perundangundangan [Pasal 25 ayat (4) UUD 1945].

d. Peradilan Tata Usaha Negara berwenang memeriksa, mengadili, memutus dan menyelesaikan sengketa tata usaha negara sesuai dengan ketentuan peraturan perundangundangan [Pasal 25 ayat (5) UUD 1945].

Berdasarkan ketentuan-ketentuan di atas, maka jelaslah bahwa penjelasan Pasal 55 huruf (d), bertentangan dengan Konstitusi. Sedangkan penjelasan Pasal 55 ayat (2) poin (a) musyawarah, poin (b). mediasi perbankan dan (c) Badan Arbitrase Syariah Nasional (Basyarnas) atau Arbitrase lainnya, menurut peneliti secara esensialnya tidak bertentangan 
dengan Undang-Undang Dasar1945, karena secara yuridis sengketa perbankan syariah ini merupakan wilayah hukum perdata (muamalah) dibenarkan penyelesaian sengketanya berdasarkan perjanjian kedua belah pihak (akad). Salah satu asas yang melekat dalam akad (perjanjian) itu adalah asas al hurriyah, asas kebebasan berkontrak/perjanjian. Para pihak yang melakukan akad mempunyai kebebasan untuk membuat suatu perjanjian (freedom of making contract), baik dalam menentukan yang diperjanjikan (objek perjanjian) maupun menentukan syarat-syaratnya termasuk menentukan cara penyelesaian jika terjadi sengketa sepanjang tidak bertentangan dengan syariat Islam. Oleh sebab itu termasuk kebebasan memilih forum hukum dalam menyelesaikan sengketa apakah dengan cara musyawarah mufakat, mediasi perbankan atau melalui Basyarnas dan lembaga arbitrase lainnya. Namun Penjelasan Pasal 55 ayat 2 ini cara penyelesaian secara non litigasi/ di luar Pengadilan terbatas dalam bentuk tiga pilihan foruma sehingga ini membatasi para pihak untuk membuat kontrak/ akad sehingga kehilanggan makna al huriyyah (kebebasan berkontrak) yang juga bertentangan dengan Pasal 28 D ayat (1) Undang- Undang Dasar 1945 adanya jaminan dan kepastiah hukum.
Dengan demikian pembatasan penyelesaian sengketa perbankan syariah secara non litigasi dalam penjelasan Pasal 55 ayat (2) seperti terteta dalam poin a, b dan c tidak sejalan dengan Konstitusi, maka semestinya tidak hanya tiga bentuk choice of forum akan tetapi lebih dari tiga bentuk tersebut, seperti. konsultasi, konsoliasi, negosiasi, dan pendapat para ahli.

\section{KESIMPULAN}

Bertolak dari hasil penelitian dan analisis yang dikemukakan dapat diambil beberapa kesimpulan, sebagai berikut.

1. Akibat hukum dari putusan Mahkamah Konstitusi Nomor 93/PUU-X/2012 terhadap penyelesaian sengketa perbankan Syariah secara litigasi adalah dihapusnya kewenangan Pengadilan dalam lingkungan Peradilan Umum (Pengadilan Negeri) untuk mengadili dan menyelesaikan sengketa perbankan syariah sejak tanggal 29 Agustus 2013, segala klausul perjanjian penyelesaian sengketa secara litigasi tidak lagi memuat Pengadilan Negeri. Kewenangan penyelesaian sengketa perbankan syariah secara litigasi adalah kewenangan absolut Pengadilan Agama yang tidak boleh diselesaikan oleh pengadilan lain sebagaimana amanah Undang-Undang 
Nomor 3 tahun 2006 Pasal 49 huruf (i) kemudian diubah lagi dengan Undang-Undang Nomor 48 Tahun 2009 yang tidak ada perubahan atas pasal tersebut;

2. Akibat Hukum dari Putusan Mahkamah Konstitusi Nomor 93/ PUU-X/2012 terhadap penyelesaian sengketa perbankan Syariah secara non litigasi melalui musyawarah, mediasi perbankan dan Badan Arbitrase Syariah Nasional (Basyarnas) adalah tidak mengikat secara hukum dan bertentangan dengan konstitusi karena terbatasnya lembaga non litigasi dalam penjelasan Pasal 55 ayat (2) tersebut segala perjanjian (akad) dibuat setelah keluarnya putusan tersebut adalah batal demi hukum dan akad tersebut harus dikembalikan/disesuaikan dengan Pasal 55 ayat (2) dan ayat (3). Penyelesaian sengketa perbankan syariah secara non litigasi adalah pilihan kedua (second choice) apabila para pihak tidak sepakat penyelesainnya melalui Pengadilan Agama, penyelesaian sengketa dimaksud melalui jalur non litigasi lebih luas seperti berbentuk musyawarah Internal, Konsultasi, Negosiasi, Konsiliasi, Penilaian para ahli, Mediasi dan Basyarnas yang dibuat kesepakatan secara tertulis yang memuat mengenai hak dan kewajiban masingmasing pihak.

\section{KEPUSTAKAAN ACUAN}

Cresswell, J. W. (2008). Educational Research: Planning, Conducting, and Evaluating Quantitative and Qualitative Research. New York, NY: Prentince Hall.

Ka'bah, Rifyal. (2009). Arbitrase Melalui BANI dan Basyarnas. Makalah disampaikan pada acara pelatihan mediasi bagi Hakim diselenggarakan Pusdiklat Teknis Mahkamah Agung RI tanggal 26 Maret 2009.

Lembaran Negara Republik indonesia Tahun 2008 Nomor 94, Tambahan Lembaran Negara Republik Indonesia Nomor 4867

Mahkamah Konstitusi. Putusan Nomor 93/ PUU-X/2012. http://www. Mahkamah Konstitusi. go.id. 29 Agustus 2013

Manan, Abdul. (2007). Beberapa Masalah Hukum Dalam Praktek Ekonomi Syariah. Banten: Makalah Diklat Calon Hakim Angkatan ke -2 Tanggal 7 Februari 2007.

Moleong, Lexy, J, (2007). Metodologi Penelitian Kualitatif. Bandung: PT. Remaja Rosdakarya 
Peraturan Bank Indonesia (PBI) Nomor 8/5/PBI/2006 tentang Mediasi Perbankan

Sugiyono. (2007). Memahami Penelitian Kualitatif. Bandung: CV. ALFABETA Undang-Undang Dasar 1945 Pasal 28

Undang-Undang Dasar 1945 Pasal 25

Undang-Undang Nomor 3 tahun 2006

Undang-Undang Nomor 4 tahun 2004 tentang kekuasaan kehakiman
Undang-Undang Nomor 7 tahun 1989 tentang Peradilan Agama

Undang-Undang Nomor 8 tahun 2011 tentang Mahkamah Konstitusi

Undang-Undang Nomor 19 Tahun 2008

Undang-Undang Nomor 21 tahun 2008 tentang Perbankan Syariah 